\title{
The Personality Factor of Conscientiousness on Skills Requirement and Fraud Risk Assessment Performance
}

\author{
Ala'a Zuhair Mansour ${ }^{1}$, Aidi Ahmi ${ }^{1} \&$ Oluwatoyin Muse Johnson Popoola ${ }^{1}$ \\ ${ }^{1}$ Tunku Puteri Intan Safinaz School of Accountancy (TISSA-UUM), Universiti Utara Malaysia, Malaysia \\ Correspondence: Ala'a Zuhair Mansour, Tunku Puteri Intan Safinaz School of Accountancy (TISSA-UUM), \\ Universiti Utara Malaysia, Malaysia.
}

Received: October 19, 2019

Accepted: January 29, 2020

Online Published: March 24, 2020

doi:10.5430/ijfr.v11n2p405

URL: https://doi.org/10.5430/ijfr.v11n2p405

\begin{abstract}
The study examines the moderation effect of the personality factor of conscientiousness on the relationship between skills (forensic accountant and auditor) and fraud risk assessment task performance in the Jordanian public sector. The forensic accountant skills denote enhanced level of capability purposely required to collect evidence in respect of fraud prevention, detection, deterrence as well as response. Whereas, the auditing standards require auditors to make available realistic guarantees in terms of sufficiency and reliability that the financial statements as a whole are free from material misstatements arising from fraud or error. Despite efforts by the government in reducing cases of fraud through a measure of reforms such as the establishment and strengthening of accountability organs and promoting global best practices for corporate organisations, fraud and financial crimes in the public sector of Jordan are still increasing. Hence, this paper develops a conceptual framework to investigate the moderating effect of conscientiousness on skills requirements and fraud risk assessment performance. The study will assist the forensic accountants and auditors working as regulators in the public sector environment concerning fraud prevention, detection, and response. It also creates awareness among accounting information users in the public sector. The paper contributes to the literature on personality factors of conscientiousness, auditing and forensic accounting, enhanced capability skills requirement, and competence (fraud risk assessment performance) by forensic accountants and auditors about fraud prevention, detection, and response in the Jordanian public sector.
\end{abstract}

Keywords: forensic accounting, fraud risk assessment, conscientiousness personality factor, public sector, Jordan

JEL Classification Code: M40, M41, M42, M48, M49

\section{Introduction}

Fraud is common worldwide, as no organisation or country will claim to be free or immune from fraud (Abdullahi \& Mansor, 2015; Popoola, 2014) because of advanced in technology, globalisation, and complex legislation. However, despite its commonness, the incidence of fraud differs in countries and organisations. Fraud is an act intended for deception to achieve personal gain or take advantage, which culminated in a loss to another party. Fraud as a crime encompasses all the multiple means that human skill can resort to and which the individual uses to gain an advantage over another through misrepresentation of facts. The increasing need to use forensic accounting in fraud investigation comes from the growing level of fraud in Jordan as a country and the world at large.

Forensic accounting services involve (a) The application of specialized knowledge and investigative skills possessed by Certified Public Accountants (CPA); (b) Collecting, analyzing and evaluating evidential matter; and (c) Interpreting and communicating findings in the courtroom, boardroom or other legal/administrative venues (Durkin and Ueltzen, 2009). Similarly, the American Institute of Certified Public Accountants (AICPA) Certified in Financial Forensics (CFF) Core Focus Wheel demonstrates the various areas of specialized forensic knowledge and core skills available to the forensic accountant. These areas comprise (a) Bankruptcy, Insolvency and Reorganization; (b) Economic Damages Calculations; (c) Computer Forensic Analysis; (d) Family Law; (e) Valuation; (f) Financial Statement Misrepresentation; and (g) Fraud Prevention, Detection and Response (Popoola, 2014; Davis et al., 2010; Durkin \& Ueltzen, 2009).

A forensic accountant, therefore, is entrusted with skills and competencies for preventing, detecting and responding to fraud (Popoola et al., 2015; Wells, 2012) as against the independent auditor that has an unbiased obligation to 
express an opinion regarding financial statements of organisations (Apostolou \& Crumbley, 2008). The capability requirements of the FA such as skills, knowledge, ethics, value, and mindset/attitude constitute the cornerstone to reduce the incidences or perpetuation of fraud and fraudulent activities (Imam et al., 2015; Popoola, 2014; Hopwood et al., 2012; Boritz et al., 2008).

Relying on prior researches, it is a well-known fact that fraud, corruption, and other wrongdoings are universal matters that touch on all areas of an economy irrespective of businesses, proportions, or nation-state. An enormous quantity of money is misplaced because of the perpetuation of some fraudulent activities. Reports obtained from the media revealed that a matter of fraud could be found in all nations, be it developed or developing. Several companies in various countries are affected, such as "HIH Insurance (Australia), Nortel Network (Canada), LCI Computer (Netherlands), Adecco Int'l (Switzerland), Versailles and Wiggins (UK) and Enron, Adelphia Comm. Xerox (US), among others" (Bhasin, 2012). Financial activities of fraudulent and scandalous nature seemed to be the burning issue for decades. Many qualified negotiators and supervisory bodies have attempted to rectify the prevailing flaws in commentary techniques (Imam et al., 2015; Bhasin, 2012).

Based on this global breakdown, which was, as a result, of the failure of "Enron, WorldCom, Parmalat" (Doering, 2002). The International Standard on Auditing (ISA) No. 240, The Auditor's Responsibilities Relating to Fraud in an Audit of Financial Statements, and (SAS) No. 99, Consideration of Fraud in a Financial Statement Audit, suggested that "the auditor may respond to an identified risk of material misstatement due to fraud by assigning the forensic specialists" (Popoola, 2014; Wuerges, 2011; AICPA, 2002).

Even though various reforms embarked by nations through legislation, laws, and edicts, as well as the establishment of organs of accountability such as anti-corruption commission, code of conduct tribunal, amongst others, fraud in the public sector continues to be on the increase (ACFE, 2018; Popoola, 2014). This may indicate that the accounting and audit management of public sector systems has failed to bring about any meaningful changes. Therefore, this study is motivated by the investigation of accounting, management and auditing systems in the Jordanian public sector (i.e., capabilities and competences requirements) in the areas of fraud prevention, detection, and response. The accounting and auditing management systems in Jordan rest squarely on the Jordanian audit bureau (JAB) and the Jordan Association of Certified Public Accountants (JACPA). By the relevant instruments of law, both agencies maintain obligations and perform oversight functions on the forensic accountant, auditor, and accountant in the Jordanian public sector.

Numerous researches on job performance (for instance, Gellatly, 1996; Barrick \& Mount, 1993) all revealed that personality predicts task performance. Conscientiousness has shown the most reliable and most consistent validities across all dimensions of all the big-5 factors, (Penney et al., 2011; Berry et al., 2007; Salgado, 2002; Borman et al., 2001; Barrick et al., 2001; Hurtz \& Donovan, 2000; Organ \& Ryan, 1995; Tett et al., 1991; Barrick \& Mount, 1991). Additionally, Emerson and Yang (2012) and Ashton (1999) studies recommended that the Big-5 factors of personality could be used or adopted as forecasters of task performance in accounting studies. Very few researches (Gullkvist \& Jokipii, 2015; Levy et al., 2011; Jaffar et al., 2008; Lehmann, 2001; Zimbelman \& Waller, 1999; Pincus, 1984) had studied the influence of the personal aspects of the capability to detect fraud. The findings revealed that the results of inconclusive studies.

Researchers have shown an increased interest in fraud prevention and detection in public sector organisations because of the solution to saving the facilities and infrastructure from collapse, taking into consideration the increase of frauds in Jordan especially, and worldwide. Fraud prevention and detection have become a matter of apprehension among business organisations globally.

Studies on fraud risk assessment (FRA) become inevitable for the public sector because it remains a reasonable way to save public organisations from fraudulent perpetrators. This paper aims to develop the conceptual framework that examines the effect of conscientiousness factor of personality (i.e., as a moderator) on the association between Skills requirements of forensic accountant and auditor and fraud risk assessment task performance in the Jordanian public sector. Therefore, the specific objectives of the study are:

(a) To examine the relationship between the capability requirement (i.e., skills) of a forensic accountant and auditor and fraud risk assessment task performance in the Jordanian public sector.

(b) To investigate the relationship between the Personality factor of Conscientiousness and fraud risk assessment task performance in the Jordanian public sector.

(c) To explore the moderating effect of the Personality factor of Conscientiousness on the relationship between the capability requirement (i.e., skills) of a forensic accountant and auditor and fraud risk assessment task performance 
in the Jordanian public sector.

The current study is limited to the Office of Accountant General, Auditor General, and Audit Bureau of Jordan. The unit of analysis consists of individuals in the areas of accounting, auditing, and forensic accounting in the Jordanian public sector.

This paper is divided into four sections. The first section deals with the introduction (motivation, problem statement, objectives, scope, and significance of study). The second section presents the literature review and the conceptual framework of the study. The third section discusses the theoretical framework of the study and hypothesis development of the study; the fourth section highlights the summary and conclusion of this study.

\section{Literature Review}

\subsection{Overview of Accounting and Auditing Profession in Jordan}

Accounting services refers to the training and examination of critical evidence of internal and external users through financial statements. Auditing services include assessing the reliability and credibility of commercial information, including "the systems and processes responsible for recording and summarising that information" (Messier et al., 2006).

The Companies Law No. 22 of 1997 represents the groundwork for fiscal reports by all parties involved and governs the corporate financial reporting framework in Jordan. Altogether, corporations are obliged to have a yearly legal check, excluding restricted and general partnerships that have an asset base, which is less than One hundred thousand Jordanian dinars (JOD100,000.00). It is specified by law that the financial reports of both public and private corporations, and limited liability companies, should be prepared in compliance with the "recognised international accounting standards," that is, the International Financial Reporting Standards issued by the International Accounting Standards Board.

The Law No. 73 of 2003 on "Organizing the Practice of the Public Accounting Profession (Accounting Act 2003)" authorises Jordanian Association of Certified Public Accountants (JACPA) to recommend auditing standards to be adopted by the Higher Committee of the Accountancy Profession (HCAP). JACPA recommended the adoption of International Auditing and Assurance Standards Board (ISA) as issued by the International Auditing and Assurance Standards Board (IAASB) for financial statement audits, and the HCAP approved the use of the standards.

The Companies Law No. 22 dated 1997 and Accountancy Law 2003 authorize the Jordanian Association of Certified Public Accountants (JACPA) and the Higher Committee of the Accountancy Profession (HCAP) to specify applicable auditing standards in Jordan. Under Accountancy Law 2003, the JACPA is responsible for recommending the auditing standards the HCAP is to adopt. In 1992, the HCAP adopted all ISA as issued by the IAASB for current and future audits.

Further to the prerequisites recognised in the 2003 Accountancy Law, Companies Law, and Law No. 28 of 2000, which regulates banking activities. It is followed by Law No. 76 of 2002, which regulates securities matters, as well as Act No. 33 of 1999 that governs and Insurance matters and the financial statement's requirements for financial institutions, which include banks and other listed companies, including insurance companies. By agreeing with the regulations and the guidelines emanating thereof, controlled entities are obliged to follow the adopted International Financial Reporting Standards (IFRS) and the Jordanian International Auditing Standards (JIAS) in preparing and presenting their financial statements and for audit purposes. The Central Bank of Jordan maintains a list of auditors who are authorised to conduct audits of banks' financial statements.

\subsection{Public Sector}

According to a definition provided by Popoola (2014) and Jones and Pendlebury (2010), refers to the public sector as "all organisations which are not privately owned and operated, but which established, run and financed by the Government on behalf of the public." As stated early, the public sector aims to offer public services, which comprises public goods and government services without the purpose to profit therein (Adams, 2006).

Public sector accounting can be defined as "a process of recording, communicating, summarising, analysing and interpreting government financial statements and statistics in aggregate and details; which is concerned with the receipts, custody and disbursement and rendering of stewardship of public funds entrusted" (Popoola, 2014; Adams, 2006). The globally accepted meaning of financial accounting is similar to this one.

\subsection{Forensic Accounting}

The term forensic accounting can be called as investigative accounting or fraud audit, which is a fusion of forensic 
science and accounting (Kasum, 2013). Hence, in this paper, the terms forensic accounting, investigative accounting, and fraud audit are used interchangeably. According to a definition provided by Hopwood, Leiner, and Young (2011), forensic accounting is "the application of investigative and analytical skills to resolve financial issues in a manner that meets standards required by courts of law." Akintunde (2019) and Curtis (2008) opined that forensic accountant is vital to the legal system because of providing professional services like counterfeit billing assessments, distrustful bankruptcy assessments, and examining the financial documents in fraud schemes.

However, in general, there is no universal meaning for forensic accounting. There may be many meanings of criminal accounting, as there are writers. According to a definition provided by The ACFE (2019) criminal accounting as "the use of skills in potential or real civil or criminal disputes, including generally accepted accounting and auditing principles in establishing losses of profit, income, property or damage, estimations of internal controls, frauds, and others that involve the inclusion of accounting expertise into the legal system." According to a definition provided by the American Institute of Certified Public Accountants (AICPA, 2010), forensic accounting is "services that involve the application of specialised knowledge and investigative skills possessed by Certified Public Accountant who utilises the practitioner's specialised knowledge and core skills of accounting, auditing, economic, tax, amongst others."

According to Baird and Zelin (2009), forensic accounting is a vital fact-finding instrument for exposing fraud. It offers an accounting analysis to courts of law concerning disagreement determination in some instances by providing the courts with reasons on pending cases. This reason accounts for the indispensable role, which may play a forensic accounting in the detection and reduction of accounting fraud in the business sector.

From the definitions presented so far, it is noteworthy to mention that criminal accounting contains the application of accounting concepts, techniques of auditing, and investigative procedures in solving legal problems. Also, worthy of reference is an emphasis that the duty of preventing and detecting fraud in financial reports lies not only in the hands of management of an enterprise but also in other control institutions.

The internal control and internal auditing system are the rudiments for the deterrence and detection of frauds that are fashioned via property misuse and, in addition to that, utilise financial statements as tools for the frauds. Forensic accounting in Kristic (2009) opinion is on guaranteeing the reliability and credibility of financial statements that can be achieved by the application of forensic accounting to expose probable several financial frauds that can utterly endanger the confidence of many users of financial information. Hence, forensic accounting reporting can be used to fill the gap so that accountability of fraud is laid down and the report considered as evidence in a court of law (Crumbley, 2009). According to Mckttrick (2009), forensic accounting mainly focuses on legal situations as well as the ability to reach beyond the legal focus in the areas of work, which may be of interest to any organisation, including the public sector.

\subsection{Fraud}

Fraud can be defined through several different conceptions, some legal; others academic, while others rely on personal experience. Fraud includes utilising dishonest means to deceitfully make personal gains for individual benefits at the expense of another.

It is necessary at the beginning to clarify what is the meaning of fraud from the lawful viewpoint, the Black's Law Dictionary defines fraud as "a knowing misrepresentation of the truth or concealment of a material fact to induce another to act to his or her detriment defines it." The Association of Certified Fraud Examiners (ACFE), describe fraud "as any illegal acts characterised by deceit, concealment, or violation of trust." Frauds are committed by individuals and organisations to obtain money, property, or services; to evade reimbursement or loss of services, or to get individual or business advantage. Furthermore, the AICPA defined fraud as "a broad legal concept that distinguished from error depending on whether the action is intentional or unintentional." Fraud as a notion is a broad term and includes all the multiple means that human beings can create, which an individual resorted, to gain an advantage over the other by false representations. There is no general definition for fraud, as it comprises astonishments, deception, crafty, and one-sided ways by which another is resentful. The only restrictions are those that bound human endeavour.

The purpose of this paper is not just to review research about fraud in the public sector but also to draw the attention on the capability requirement (i.e., skills) and competence requirement (i.e., fraud risk assessment task performance) of the numerous structures in preventing, detecting and deterring fraud via the instrumentality of a realistic and capable application of the many regulations. 


\subsection{Fraud Risk Assessment Task Performance (FRATP)}

The terms 'fraud' and 'fraud risk' are using interchangeably. "Fraud" and "fraud risk" are ontologically dissimilar (Power, 2013). Fraud is related to the certainty of an occurrence, whereas fraud risk deals with the likelihood of the incident. Precisely, fraud is a deliberate action by one or additional persons by means dishonesty to acquire an unmerited or illicit benefit.

Nevertheless, fraud risk contains components of probabilities of the event that occurred. Consequently, the tactic of handling fraud and fraud risk can be different. Fraud deals with actuality and the method to resolve fraud is by investigating the fraud happening itself. Equally, fraud risk contains only the likelihood of fraud that can occur, and consequently, it must be managed by the organisation (Power, 2013).

The Committee of Sponsoring Organisations of the Tredway Commission (COSO) 2016 defined the assessment of fraud risk as "The organisation performs comprehensive fraud risk assessments to identify specific fraud schemes and risks, assess their likelihood and significance, evaluate existing fraud control activities, and implement actions to mitigate residual fraud risks."

Carrying out a risk assessment on fraud ought to be done consistently to determine the possible plans and events that need to be evaluated and thus offers guidance for Fraud Risk Assessment procedures. Nevertheless, modifications are required to achieve the organisation of individual needs and complexities (ACFE, 2016). According to the AICPA in "Managing the Business Risk of Fraud: A Practical Guide" (2009), which states:

"An efficient FRA ought to determine where fraud might happen and who the perpetrators might be. Therefore, control activities should always consider both the fraud scheme and the individuals within and outside the organisation who could be the perpetrators of each scheme. If the scheme is collusive, preventive controls should be augmented by detective controls, as collusion negates the control effectiveness of segregation of duties".

Fraud, by its term, involves wilful misconduct, designed to evade detection. As such, the risk of fraud must be assessed to participate in strategic thinking to anticipate the behaviour of the perpetrator of potential fraud teams (Boritz \& Timoshenko, 2014). As noted by (AICPA) and (ACFE), fraud risk evaluation must include three rudiments: (1) Identify inherent fraud risk; (2) Assess likelihood and significance of inherent fraud risk; and (3) Respond to specific and potential inherent and potential fraud risks.

\subsection{Skills (Forensic Accountant and Auditor)}

The accountants, auditors, and forensic accountant in the public sector require specific skills to look at the evidence from different views to determine various potential clarifications of that evidence and the consequences of those explanations of the current matter. Criminal accounting is a growing area of accounting practices that provide complementary skills and experience with the capabilities of the investigation and applied for disclosure of evidence of fraud (Nicolae \& Diana, 2017). In recent years, scholars commenced querying what specific skills and technical capabilities must be available in an FA and auditor to discover fraud (Ademola et al., 2017; Popoola, 2015; Arežina et al., 2014; Ramaswamy, 2005; Messmer 2004).

In 2003, Grippo and Ibex's study demonstrated and argued that "the most important skills of FA's come from experience in accounting and auditing, taxation, business operations, management, internal controls, interpersonal relationships, and communication". In searching for the skills required of a forensic accountant and auditor, Popoola (2014) and DiGabriele (2008), in their studies, adopted nine (9) essential indicators for measuring skills. The skills are (a) Unstructured problem solving; (b) Critical thinking; (c) Deductive analysis; (d) Oral communication; (e) Analytical proficiency; (f) Investigative flexibility; (g) Legal knowledge; (h) Written communication; and (i) Composure. Davis, Farrell, and Ogilby (2010) highlight the skills of a Forensic Accountant, the results of this study indicate that the analytical characteristics, communication skills and the capability to simplify complexity, and the capability to state opinions on the lawful status are critical to the effectiveness of the forensic accountant. It should also be a forensic accountant's ability to see the future combine with logical facts and detailed analysis of fraud risk assessment tasks.

International Education Standard No.3 describes forensic accounting skills as professional skills, and essential capabilities required by a professional accountant to display his abilities. International Federation of Accountants (IFAC) recommended the needed skills as technical skills, intellectual skills, and interpersonal skills (Popoola et al., 2016; IFAC-IES 3, 2014). Therefore, possessing the skills will enable the forensic accountant and auditor to design procedures to reduce the incidence of fraud in the public sector environment. 


\subsection{Conscientiousness as a Personality Factor}

The effect of personality as a dominant influence on task performance has been dealt with through the present century in numerous studies and meta-analyses across many nations and cultures to comprehend how personality factors can affect task performance (such as performance of fraud risk assessment). Over the years, researchers have identified many traits of personality that may represent individual characteristics (McCrae \& Terracciano, 2005; McCrae \& Costa, 1997). For example, the Big-5 Model ("extraversion, neuroticism, conscientiousness agreeableness and openness to experience") reflects human behaviour and reaction in a different context such as Job performance (Trouba, 2009; Vakola et al., 2004).

After reviewing the accounting literature, a few studies found on the impact between Personality factors and auditor's behaviour (Asni et al., 2018; Donelly et al., 2003; Dole \& Schroeder, 2001; Tsui \& Gul, 1996), the judgment made by auditors' (Tsunogaya et al., 2017; Lehmann, 2001), workload and job exhaustion (Law, 2003) and managers' opinion (Hartmann, 2005). These studies found diverse findings regarding the impact of the personality factors on the dependent variables.

Conscientiousness is a communally given instinct controller which enables thoughtfulness before taking action, deferring indulgence, adhering to be prescribed standards and guidelines, to be answerable, to be reliable, to be success focused, to be used to liking order, doing planning, to be determined, to be organized, to be systematic, and prioritizing (Mount et al., 2006; Barrick \& Mount, 1991; Costa, McCrae \& Dye, 1991;). Conscientiousness is the most constant factor among the big five, revealing robust stability over a high number of years (Judge et al., 1999).

Conscientiousness is the personality dimension primarily in charge of organising and guiding a person behaviour, and conscientious persons may consider as accountable, ethical, hard-working, resolute, and systematic (Becker, 1998).

Earlier investigations have established an association between conscientiousness and performance, and this relation was revealed consistently over the years (Barrick et al., 1993). Conscientiousness is the most influential personality predictor of job performance (Barrick et al., 2001). Nevertheless, no study, particularly in the accounting field, has specifically examined the moderating influence of conscientiousness on the association among a variable and task performance.

Previous studies offer diverse findings concerning the impact of conscience on task performance (e.g., Hassan et al., 2016; Jiang et al., 2009; Kraus, 2002; Lehmann, 2001; Mount et al., 1998; Gellatly, 1996; Barrick \& Mount, 1993; Barrick \& Mount, 1991). This study posits that a person with a high level of conscience should perform well. Hence, having characteristics as being detail consciousness, organised, and reliable are critical factors for conduction auditing tasks.

\section{Conceptual Framework and Hypotheses Development}

A conceptual framework refers to a structure of rules, assumptions, and principles, which holds together ideas concerning a specific concept (Mugenda \& Mugenda, 2003). The purpose of the conceptual framework is to investigate the moderating influence of conscientiousness, forensic accountant and auditor's skills capability on fraud risk assessment task performance in the Jordanian public sector as Figure 1 presents the proposed research framework of the study.

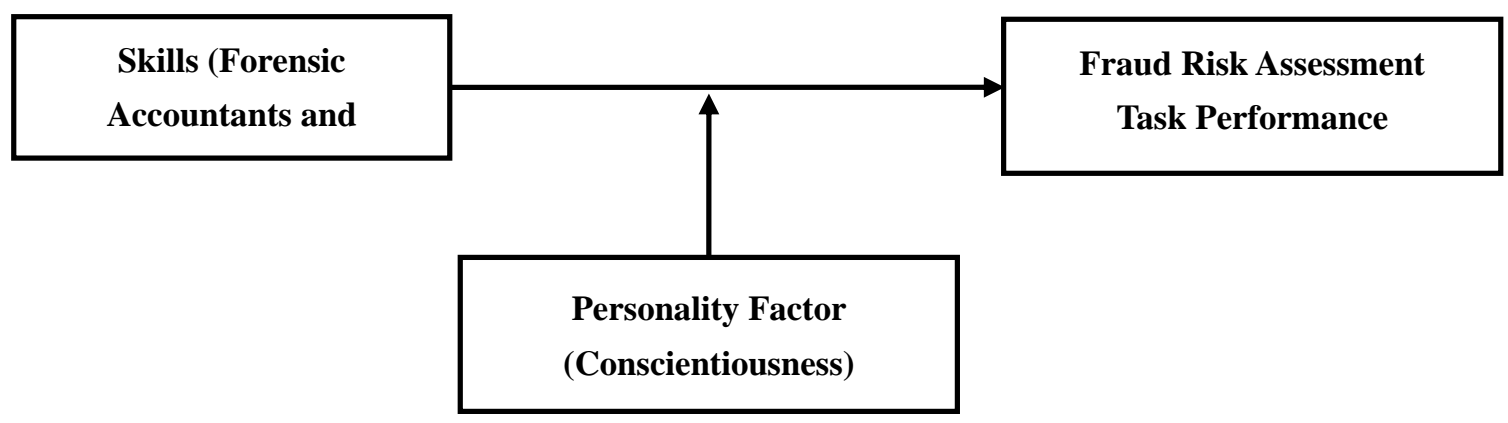

Figure 1. The Conceptual Framework of the study 


\subsection{The Relationship Between Skills (Forensic Accountants and Auditors) and Fraud Risk Assessment Performance in the Jordanian Public Sector}

The skills of the FA and auditor represent the skills that are advanced primarily to collect evidence to detect, prevent, and respond to fraud. Firstly, the conceptual connection in this study outline signifies the possibility that skills (forensic accountant and auditor) do influence fraud risk assessment task performance. Previous studies provide empirical evidence show that any additional skill difference can lead to significant differences in the individual behaviour, which in turn affects the fraud risk assessment task performance (Popoola et al. 2015; Davis et al., 2010; DiGabriele, 2008). Other studies assume that a small change in skills would lead to significant improvements in the fraud risk assessment task performance (Popoola et al. 2015; Chui, 2010; Davis et al., 2010; DiGabriele, 2008). Criminal accounting is a growing area of practice in which advanced accounting skills and abilities are integrated with investigative expertise and applied for detecting fraud evidence (Nicolae \& Diana, 2017; Popoola et al., 2016). Hence, a forensic accountant and auditor skills requirements have a direct effect on fraud risk assessment task performance. Therefore, the hypothesis is formulated as follows:

H1: There is a significant positive relationship between the skills of a forensic accountant and auditor and fraud risk assessment performance in the Jordanian public sector.

3.2 The Relationship Between Conscientiousness and Fraud Risk Assessment Performance in the Jordanian Public Sector

Previous studies have proven the linkage between conscientiousness and task performance (Kamdar \& Van Dyne, 2007; Barrick \& Mount, 1991). In fraud detection researches, very few studies (Gullkvist \& Jokipii, 2015; Levy et al., 2011; Jaffar et al., 2008; Lehmann, 2001; Zimbelman \& Waller, 1999; Pincus, 1984) had studied the consequence of personality influence on the capability to detect fraud. Conscientious individuals maintain control over socially prescribed motivations (e.g., thoughtfulness before doing an action, delaying gratification, preparation, arranging, and subsequent guidelines and standards) that improves performance (John \& Srivastava, 1999). McCrae and Costa (1999) suggested that individuals of conscience frequently have long-term plans, technical expertise, and an organised support network. Meta-analytic researches indicated that conscientiousness is the most generalizable Big-5 predictor of task performance (e.g., Barrick et al., 2001). Investigations on meta-analysis also revealed that the existence of moderators, including about three initial studies which have established that situational moderators influence conscientiousness-job performance relationship (Gellatly, 1996; Barrick \& Mount, 1993; Barrick et al., 1993). Employees high in conscientiousness are inclined to be ordered, thorough, well organised, diligent, reliable, systematic, and focussed. They tend to be better than low-conscientiousness employees in being systematically and properly achieve work tasks, to take ingenuity in cracking difficulties, to be dedicated to work performance, to fulfil with guidelines, and to stay attentive on work tasks. We, therefore, propose that:

H2: There is a significant positive relationship between conscientiousness as a personality factor and fraud risk assessment task performance in the Jordanian public sector.

\subsection{The Moderating Effect of Conscientiousness on Capability Requirements (Skills) and Fraud Risk Assessment} Task Performance in the Jordanian Public Sector

Studies have presented mixed findings relating to the influence of conscientiousness on task performance (e.g., Tsunogaya et al., 2017; Hassan et al., 2016; Jiang et al., 2009; Kraus, 2002; Mount et al., 1998; Gellatly, 1996; Stewart \& Carson, 1995; Barrick \& Mount, 1993; Barrick \& Mount, 1991). The current research forecasts that a person with a high level of conscientiousness would fare better in his / her occupation for the reason that features such as being prepared, dependable, paying attention to details, and plan full are vital factors for performing auditing tasks. Consequently, the current research suggests that given risk conditions of any kind, high on conscientiousness have a positive impact on the linkage between the forensic accountant and auditors to assess fraud risk and their capability to detect fraud if one occurs. Thus, the hypothesis is formulated as follows:

H3: Conscientiousness as a personality factor positively moderates the relationship between the skills of the forensic accountant and auditor and Fraud risk assessment task performance in the Jordanian public sector.

\section{Conclusion}

This paper discussed the interaction effect of conscientiousness on the capability requirement - skills of a forensic accountant and auditor and Fraud risk assessment task performance in the Jordanian public sector and thus has expanded the literature on fraud prevention, detection and response. The research aids in complementing the accounting and auditing management systems in the areas of fraud prevention, detection, and response, especially in the Jordanian public sector environment. Additionally, this study creates awareness among the Jordanian 
professionals in accounting, auditing and assurance through a review of prior literature on capability requirements (skills) and personality factor of conscientiousness (that is, the moderator) and Fraud risk assessment task performance in the Jordanian public sector.

This study hopes to likely draw the attention of users of public sector forensic accountants and auditors such as regulatory and enforcement bodies, courts, ministries, departments, and agencies towards the understanding of the mechanisms of fraud schemes and the capability to prevent, detect and respond to fraud requires a holistic approach.

This research will add to a growing body of literature on forensic accounting and financial criminology with emphasis on capability (skills), and competence (fraud risk assessment) regarding fraud prevention, detection and response in the Jordanian public sector.

This research is subject to certain limitations, as with any conceptual study. First, it is about fraud and corrupt practices in a developing country, Jordan. Second, the moderation effect of conscientiousness on skills and fraud risk assessment performance in the Jordanian public sector could be measured as sensitive, and thus, raise the issue of such a bias. The present study is theoretical, and hence, future empirical research will be conducted to assess the significance of the proposed model in the performance of fraud risk assessment.

\section{References}

Abdullahi, R., \& Mansor, N. (2015). Forensic accounting and fraud risk factors: the influence of fraud diamond theory. The American Journal of Innovative Research and Applied Sciences, 1(5), 186-192.

Adams, R. A. (2006). Public sector accounting and finance made simple. Corporate Publishers Ventures.

Ademola, L. S., Che-Ahmad, A., \& Popoola, O. J. M. (2017). The Forensic Accountants' Skills and Ethics on Fraud Prevention in the Nigerian Public Sector. Academic Journal of Economic Studies, 3(4), 77-85.

Akintunde, A. (2019). Contemporary issues in Forensics Accounting and Forensics Audit. Journal of Accounting, Finance, and Development (JAFID), 2(1), 149-166.

American Institute of Certified Public Accountants. Auditing Standards Board. (2002). Consideration of Fraud in a Financial Statement Audit (supersedes Statement on Auditing Standards No. 82, AICPA, Professional Standards, Vol. 1, AU Sec. 316; and Amends SAS No. 1, Codification of Auditing Standards and Procedures, AICPA, Professional Standards, Vol. 1, AU Sec. 230," Due Professional Care in the Performance of Work," and SAS No. 85, Management Representations, AICPA, Professional Standard, Vol. 1, AU Sec 333). American Institute of Certified Public Accountants.

Apostolou, N., \& Crumbley, D. L. (2008). Auditors' Responsibilities with respect to Fraud: A Possible Shift?. The CPA Journal, 78(2), 32.

Arežina, N., Knežević, G., Simeunović, N., \& Vukićević, S. (2014). Forensic accountant: innate trait or an acquired skill?. In The Proceedings of Singidunum University International Scientific Conference: Finiz 2014 (pp. 131-134). Belgrade. https://doi.org/10.15308/finiz-2014-131-134

Ashton, R. H. (1999). Enriching the "expertise paradigm" of accounting research: Conscientiousness, general cognitive ability, and goal orientation. Advances in Accounting Behavioural Research, 2, 3-14.

Asni, N., Dali, N., Dharmawaty, T., \& Syafitri, A. A. (2018). The Influence of Locus of Control and Professional Commitment toward Auditor's Behaviour in Conflict Situation. Journal of Economics and Finance (IOSR-JEF), 9(4), 75- 83.

Association of Certified Fraud Examiners. (2010). Report to the Nation: Occupational Fraud and Abuse. Retrieved from https://www.acfe.com/report-to-the-nations/2010

Association of Certified Fraud Examiners. (2018). Report to the Nation: Occupational Fraud and Abuse. Retrieved from https://www.acfe.com/report-to-the-nations/2018

Association of Certified Fraud Examiners. (2019). Forensic Accountant. Retrieved from https://www.acfe.com/forensic-accountant.aspx

Baird, J. E., Zelin, I. I., \& Robert, C. (2009). An Examination of the Impact of Obedience Pressure on Perceptions of Fraudulent Acts and the Likelihood of Committing Occupational Fraud. Journal of Forensic Studies in Accounting \& Business, 1(1).

Barrick, M. R., \& Mount, M. K. (1991). The big five personality dimensions and job performance: a meta - analysis. Personnel Psychology, 44(1), 1-26. https://doi.org/10.1111/j.1744-6570.1991.tb00688.x 
Barrick, M. R., \& Mount, M. K. (1993). Autonomy as a moderator of the relationships between the Big Five personality dimensions and job performance. Journal of Applied Psychology, 78(1), 111-118.

Barrick, M. R., Mount, M. K., \& Judge, T. A. (2001). Personality and Performance at the Beginning of the New Millennium: What Do We Know and Where Do We Go Next?. International Journal of Selection and Assessment, 9(1/2), 9-30. https://doi.org/10.1111/1468-2389.00160

Barrick, M. R., Mount, M. K., \& Strauss, J. P. (1993). Conscientiousness and performance of sales representatives: Test of the mediating effects of goal setting. Journal of Applied Psychology, 78(5), 715-722.

Berry, C. M., Ones, D. S., \& Sackett, P. R. (2007). Interpersonal deviance, organisational deviance, and their common correlates: A review and meta-analysis. Journal of Applied Psychology, 92(2), 410.

Bhasin, M. L. (2013). Corporate Accounting Fraud: A case study of Satyam Computers Limited. Open Journal of Accounting, 2, 26-38. https://doi.org/10.4236/ojacct.2013.22006

Boritz, J. E., \& Timoshenko, L. M. (2014). On the use of checklists in auditing: A commentary. Current Issues in Auditing, 8(1), C1-C25. https://doi.org/10.2308/ciia-50741

Boritz, J. E., Kotchetova, N., \& Robinson, L. A. (2008). Planning Fraud Detection Procedures: Fraud Specialists vs. Auditors. Working Paper, University of Waterloo.

Borman, W. C., Penner, L. A., Allen, T. D., \& Motowidlo, S. J. (2001). Personality predictors of citizenship performance. International Journal of Selection and Assessment, 9(1-2), 52-69.

Chui, L. (2010). An experimental examination of the effects of fraud specialist and audit mindsets on fraud risk assessments and on the development of fraud-related problem representations. The University of North Texas.

Committee of Sponsoring Organizations of the Treadway Commission. (2013). Fraud Risk Management Guide. In COSO. New York, United States.

Costa, P. T. Jr., McCrae, R. R., \& Dye, D. A. (1991). Facet scales for agreeableness and conscientiousness: A revision of the NEO Personality Inventory. Personality and Individual Differences, 12(9), 887-898.

Crumbley, D. L. (2009). So what is forensic accounting?. The ABO Reporter, 9.

Curtis, G. E. (2008). Legal and Regulatory Environments and Ethics: Essential Components of a Fraud and Forensic Accounting Curriculum. Issues in Accounting Education, 23(4), 535-543.

Davis, C., Farrell, R., \& Ogilby, S. (2010). Characteristics and Skills of the Forensic Accountant. American Institute of Certified Public Accountants, 11-26.

Diana, D. (2017). The Relevant Skills for Forensic Accountants - Can the Romanian Accounting Education Programs offer them? Bobițan Nicolae. "Ovidius" University Annals, Economic Sciences Series, 17(1), 419-423.

Digabriele, J. A. (2008). An Empirical Investigation of the Relevant Skills of Forensic Accountants. Journal of Education for Business, 83(6), 331-338. https://doi.org/10.3200/JOEB.83.6.331-338

Doering, J. (2002). Sarbanes-Oxley Act of 2002.

Dole, C., \& Schroeder, R. G. (2001). The impact of various factors on the personality, job satisfaction, and turnover intentions of professional accountants. Managerial Auditing Journal, 16(4), 234-245.

Donnelly, D., Quirin, J., \& O’Bryan, D. (2003). Auditor acceptance of dysfunctional behaviour: An explanatory model using auditors' personal characteristics. Behavioural Research in Accounting, 15, 87-110.

Emerson, D., \& Yang, L. (2012). Perceptions of auditor conscientiousness and fraud detection. Journal of Forensic \& Investigative Accounting, 4(2), 110-141.

Gellatly, I. R. (1996). Conscientiousness and task performance: Test of a cognitive process model. Journal of Applied Psychology, 81(5), 474-482. https://doi.org/10.1037/0021-9010.81.5.474

Grippo, F. J., \& Ibex, J. W. (2003). Introduction to forensic accounting. National Public Accountant, 4-5.

Gullkvist, B., \& Jokipii, A. (2015). Factors influencing auditors' self-perceived ability to assess fraud risk. Nordic Journal of Business, 64(1), 40-63.

Hartmann, F. (2005). The Effects of Tolerance for Ambiguity and Uncertainty on the Appropriateness of Accounting Performance Measures. ABACUS, 41(3), 241-264. https://doi.org/10.1111/j.1467-6281.2005.00181.x 
Hassan, S., Akhtar, N., \& Y1lmaz, A. K. (2018). Impact of the Conscientiousness as a Personality Trait on both Job and Organizational Performance. Journal of Managerial Sciences, 10(1), 0-14.

Hopwood, W. S., Leiner, J. J., \& Young, G. R. (2011). Forensic accounting and fraud examination. McGraw-Hill.

Hurtz, G. M., \& Donovan, J. J. (2000). Personality and job performance: The Big Five revisited. Journal of Applied Psychology, 85(6), 869. https://doi.org/10.1037/0021-9010.85.6.869

Imam, A., Kumshe, A. M., \& Jajere, M. S. (2015). Applicability of forensic accounting services for financial fraud detection and prevention in the public sector of Nigeria. International Journal of Information Technology and Business Management, 40(1), 136-152.

Jaffar, N., Salleh, A., Iskandar, T. M., \& Haron, H. (2008). The effect of the external auditors' ability to assess fraud risk on their ability to detect the likelihood of fraud. International Journal of Management Perspectives, l(1), 49-70.

Jaffar, N., Haron, H., Mohd Iskandar, T., \& Salleh, A. (2011). Fraud Risk Assessment and Detection of Fraud: The Moderating Effect of Personality. International Journal of Business and Management, 6(7), 40-50.

Jiang, C., Wang, D., \& Zhou, F. (2009). Personality traits and job performance in local government organisations in China. Social Behaviour and Personality: An International Journal, 37(4), 451-457.

John, O. P., \& Srivastava, S. (1999). The Big Five trait taxonomy: History, measurement, and theoretical perspectives. Handbook of personality: Theory and Research, 2, 102-138.

Jones, R., \& Pendlebury, M. (2010). Public sector accounting (6th ed.). New Jersey: Pearson Education, Inc.

Judge, T. A., Higgins, C. A., Thoresen, C. J., \& Barrick, M. R. (1999). The big five personality traits, general mental ability, and career success across the life span. Personnel Psychology, 52(3), 621-652.

Kamdar, D., \& Van Dyne, L. (2007). The joint effects of personality and workplace social exchange relationships in predicting task performance and citizenship performance. Journal of Applied Psychology, 92(5), 1286.

Kasum, A. (2009). The relevance of forensic accounting to financial crimes in the private and public sectors of third world economies: A study from Nigeria. Proceedings of the 1st International Conference on Governance Fraud Ethics and Social Responsibility (pp. 1-14). https://doi.org/10.2139/ssrn.1384242

Kraus, E. (2003). Personality and job performance: The mediating roles of leader-member exchange quality and action control. ProQuest Information \& Learning.

Krstić, J. (2009). The role of forensic accountants in detecting frauds in financial statements. Facta Universitatis, 6(3), 295-302.

Law, D. W. (2003). An examination of personality traits as moderating factors of exhaustion in public accounting. Washington State University.

Lehmann, C. M. (2001). The effects of experience, instruction, and personality factors on complex problem representation and performance in auditing: An experimental investigation. Unpublished Doctoral Dissertation, Texas A\&M University, USA.

Levy, J. J., Richardson, J. D., Lounsbury, J. W., Stewart, D., Gibson, L. W., \& Drost, A. W. (2011). Personality Traits and Career Satisfaction of Accounting Professionals. Individual Differences Research, 9(4).

McCrae, R. R., \& Costa, P. T. (1997). Personality trait structures as a human universal. American Psychologist, 52(5), 509-516. https://doi.org/10.1037/0003-066X.52.5.509

McCrae, R. R., \& John, O. P. (1992). An Introduction to the Five-Factor Model and Its Applications. Journal of Personality, 60(2), 175-215. https://doi.org/10.1111/j.1467-6494.1992.tb00970.x

McCrae, R. R., \& Terracciano, A. (2005). Universal features of personality traits from the observer's perspective: data from 50 cultures. Journal of Personality and Social Psychology, 88, 547-561.

McKittrick, C. (2009). Forensic Accounting: It is Broader than You Might Think and It Can Help Your Organization. The McKittrick Report, 1, 1-3.

Messmer, M. (2004). Exploring options in forensic accounting. National Public Accountant, 5(3), 19-20.

Morang, S., \& Sobel, P. (2017). Turning up the heat on fraud: a fraud risk assessment can help auditors take the organisation's ethical temperature. Internal Auditor, 74(1), 18-20. 
Mount, M. K., Barrick, M. R., \& Stewart, G. L. (1998). Five-Factor Model of personality and Performance in Jobs Involving Interpersonal Interactions. Human Performance, 11(2-3), 145-165.

Mount, M., Ilies, R., \& Johnson, E. (2006). Relationship of personality traits and counterproductive work behaviours: The mediating effects of job satisfaction. Personnel Psychology, 59(3), 591-622.

Mugenda, O., \& Mugenda, A. (2003). Research methods: Quantitative and Qualitative Methods. Revised in Nairobi.

Organ, D. W., \& Ryan, K. (1995). A meta-analytic review of attitudinal and dispositional predictors of organisational citizenship behaviour. Personnel Psychology, 48(4), 775-802.

Penney, L. M., David, E., \& Witt, L. A. (2011). A review of personality and performance: Identifying boundaries, contingencies, and future research directions. Human Resource Management Review, 21(4), 297-310.

Pincus, V. K. (1984). Fraud detection ability: Individual differences and their relationship to cognitive style difference. Unpublished Doctoral Dissertation, The University of Maryland, USA.

Popoola, O. M. J. (2014). Forensic accountants, auditors and fraud capability and competence requirements in the Nigerian public sector. Doctoral Dissertation, Universiti Utara Malaysia.

Popoola, O. M. J., Che-Ahmad, A. B., \& Samsudin, R. S. (2015). An empirical investigation of fraud risk assessment and knowledge requirement on fraud-related problem representation in Nigeria. Accounting Research Journal, 28(1), 78-97. http://doi.org/10.1108/ARJ-08-2014-0067

Popoola, O. M. J., Che-Ahmad, A. B., Samsudin, R. S., Salleh, K., \& Babatunde, D. A. (2016). Accountants' Capability Requirements for Fraud Prevention and Detection in Nigeria. International Journal of Economics and Financial Issues, 6(S4), 1-10.

Power, M. (2013). The apparatus of fraud risk. Accounting, Organizations, and Society, 38(6-7), 525-543.

Ramaswamy, V. (2005). Corporate Governance and the Forensic Accountant. The CPA Journal, 68-70.

Richards, D., Melancon, B., \& Ratley, J. (2009). Managing the business risk of fraud: A practical guide. Sponsored by: The Institute of Internal Auditors (IIA), The American Institute of Certified Public Accountants (AICPA), and Association of Certified Fraud Examiners (ACFE).

Rose, C. L., Murphy, L. B., Byard, L., \& Nikzad, K. (2002). The Role of the Big Five Personality Factors in Vigilance Performance and Workload. European Journal of Personality, 16(3), 185-200.

Salgado, J. F. (2002). The Big Five personality dimensions and counterproductive behaviours. International Journal of Selection and Assessment, 10(1-2), 117-125. https://doi.org/10.1111/1468-2389.00198

Stewart, G. L., \& Carson, K. P. (1995). Personality dimensions and domains of service performance: A field investigation. Journal of Business and Psychology, 9(4), 365-378. https://doi.org/10.1007/BF02230976

Tett, R. P., Jackson, D. N., \& Rothstein, M. (1991). Personality measures as predictors of job performance: A meta ${ }^{-}$analytic review. Personnel Psychology, 44(4), 703-742.

Trouba, E. J. (2009). A person-organisation fit study of the big five personality model and attraction to organisations with varying compensation system characteristics. Pro Quest Information \& Learning.

Tsui, J. S., \& Gul, F. A. (1996). Auditors' behaviour in an audit conflict situation: A research note on the role of locus of control and ethical reasoning. Accounting, Organizations, and Society, 21(1), 41-51.

Tsunogaya, N., Sugahara, S., \& Chand, P. (2017). The Impact of Social Influence Pressures, Commitment, and Personality on Judgments by Auditors: Evidence from Japan. Journal of International Accounting Research, 16(3), 17-34. https://doi.org/10.2308/jiar-51761

Tupes, E. C., \& Christal, R. E. (1992). Recurrent personality factors based on trait ratings. Journal of Personality, 60(2), 225-251. https://doi.org/10.1111/j.1467-6494.1992.tb00973.x

Vakola, M., Tsaousis, I., \& Nikolaou, I. (2004). The role of emotional intelligence and personality variables on attitudes toward organisational change. Journal of Managerial Psychology, 19(2), 88-110.

Wells, J. T. (2005). Accountants need help fighting the war on fraud; ACFE founder urges antifraud education Press Release.

Zimbelman, M. F., \& Waller, W. S. (1999). An Experimental Investigation of Auditor-Auditee Interaction under Ambiguity. Journal of Accounting Research, 37(1999), 135-155. https://doi.org/10.2307/2491349 